\title{
Governing prostitution in colonial Delhi: from cantonment regulations to international hygiene (1864-1939)
}

In many senses Mark Crinson is justified in arguing that: 'Delhi is probably the most studied of all modern colonial cities, the pre-eminent test case of postcolonial urban studies. ${ }^{1}$ It has been written about in terms of its ancient capitals, and the construction in the $17^{\text {th }}$ century of the final Mughal capital, Shahjahanabad. Its experiences under the East India Company residency between 1803 and 1857 have been variously reflected upon as a time of governmental experimentation, a 'golden calm' of cosmopolitanism, or a turbulent period of religious strife. ${ }^{2}$ The $150^{\text {th }}$ anniversary of the uprising of 1857 has led to recent reflection upon Delhi's role in the rise and fall of the 'Mutiny'. Its subsequent period as a recovering city, administered by the Punjab, has been less extensively covered compared with the transformation of the city that took place after the transfer of the capital of British India from Calcutta to Delhi in $1911 .^{4}$ The new capitol has been extensively studied as a space of residential segregation, town planning, and architectural innovation, which in many ways interacted with the pre-existing capital, now demoted in name and status as 'Old Delhi'. ${ }^{5}$ The city's fate as a 'partition city' after independence in 1947 is gaining increasing attention, as has its post-colonial development. ${ }^{6}$

These studies are replete with sensitive accounts of the city's development in terms of, for instance, Islamic culture, municipal politics and planning, urban improvement, and partition memories. There are, however, still many gaps in the literature on Delhi, especially when compared with the extensive historiographies of colonial Bombay and Calcutta. One of these gaps is temporal; there is little sense of the continuities and discontinuities across Delhi's periods of political status, with the broader social history of its time as the capital of British India particularly understudied. A second gap is governmental; while Delhi has been studied as an imperial capital, both Mughal and British, the development of local government and the degree 
of its engagement with the local population has not generated sufficient attention. This paper targets both these shortcomings through an analysis that spans Delhi's period of recovery after the uprising of 1857, through to the experiences of Old Delhi during its incorporation into the capital region. This analysis will use the example of the regulation of prostitution to explore the changing nature of the colonial state. It will highlight a shifting focus from the health solely of the military to that of the population more broadly. It also charts the emergence of different actors who took an interest in the regulation of prostitution, from the military, local government and repealists in the nineteenth century to social and moral hygienists in the twentieth.

The study of prostitution and its regulation is well established as a vital field for examining the nexus of sexuality, gender, class and race. This has been especially well researched in the context of Victorian Britain, building upon Walkowitz's and McHugh's foundational studies of prostitution, the Contagious Diseases (CD) Acts of 1864-68 and the female-led campaigns for their repeal. ${ }^{7}$ Other studies have emphasised the new inscription of sexuality within sanitary discourses, the oppressive physicality of the lock hospitals, the impact of the female campaigns on women's rights and aspirations, the relationship between the new laws and the state, private versions of the acts, and the post-CD Acts reforms. ${ }^{8}$

Whilst Stoler has drawn upon Foucault to suggest that metropolitan sexualities were informed by imperial circuits of power and identity, others have sought to examine the sexual politics of colonialists in the periphery. ' Hyam's interpretation of imperialism as a hydraulic, libidinal release for repressed British youth has been tempered by studies which have sought out the construction and regulation of contingent sexual relations in the social spaces of empire..$^{10}$

The last thirty years have produced a rich vein of studies exploring the social and political histories of prostitution in nineteenth century India. These have charted the colonial forms of regulation that were adapted to broader imperial needs, the imported Indian Contagious Diseases Acts (1868), their contestation and repeal (1888), the cantonment regulations which preceded and succeeded them, and the various types of prostitution in the subcontinent. These 
have ranged from the magisterial overview to international comparative studies, racial sociologies, political histories, to focused studies of the brothel, the lock hospital, or particular regions. ${ }^{11}$

This paper will establish the urban tailoring of the cantonment regulations to the social and physical topography of Delhi in the nineteenth century. As part of the reorganisation of the city after 1857 the Mughal Palace had been converted into a military barracks, including the cantonment, and had been renamed the Fort. The Palace was to the east of the dense townscape of Delhi but still within the city walls, and thus in close proximity to the population. While larger numbers of troops were stationed in the city immediately after the uprising, by 1872 the Fort contained 532 troops. ${ }^{12}$ As the discussion of the lock hospital reports will show, it is impossible to estimate the number of prostitutes in the city; even those used by the soldiery is an estimate due to the ineffectiveness of measures taken to force registration. The intensely local focus of this paper will highlight the differences between regulation in plan and in practice, the difficulties of extending military procedures to civilian populations, the resistance by the prostitutes themselves, and the effects of two unequal systems of surveillance upon the residential geographies of Delhi's prostitutes, which forced a new range of measures to be adopted in the twentieth century.

The second section of this paper will contribute to the more limited literature regarding twentieth century geographies of prostitution regulation in India. Many studies have followed Ballhatchet in assuming that, with the decline in soldiers' venereal disease rates between 1901-09, the regulation of prostitution became less problematic. ${ }^{13}$ While some authors have engaged with local twentieth century policies, the complex new measures which emerged in the early years of the century are still mostly unexplored in their full international and policy contexts. The second half of this paper reflects the diversification of agencies seeking to contribute to the governing of prostitution in twentieth century Delhi. It does this by adopting a more synchronic approach to 
the different discourses, people and institutions which sought to influence the policies of the Delhi Administration.

The prostitution regulations in the twentieth century also originated outside India, but these were as much international as imperial origins, linking developments in 'imperial hygiene' to those in British social hygiene, the League of Nations, and international abolitionist movements; that is, to an international biopolitics. ${ }^{14}$ These networks force a study of Delhi neither solely as the capital of British India, nor as mediator between imperial core and colonial periphery, nor as the coordinating capital of the Indian Ocean arena. Rather, the city emerges as an international relational space which transported happenings in New York, Geneva, London and elsewhere straight into the lanes and bazaars of Old Delhi. ${ }^{15}$

This historical transition was not just one of legislation, nor of spatial formations, but of power relations. A broadly Foucauldian framework is here used to explain the transitions that took place between the 1860s and 1930s in Delhi. Scholars of South Asia have produced a rich seam of literature which tests the applicability of Foucault's thinking to colonial India. ${ }^{16}$ Relating directly to medicine and epidemics in nineteenth century India, Arnold has emphasised the overbearing role of the state, but also the importance of resistance and failure in attempts to 'colonize the body'. ${ }^{17}$ In this light, it is possible to see that the military system of locating diseased/abnormal bodies and placing them under surveillance/discipline to make them safe/productive, sought to discipline polluting and subversive women. ${ }^{18}$ Building on earlier interpretations of India, but also on more recent work on the intersection of disciplinary power and more welfarist programmes of governmentality, there is some evidence of a twentieth century move towards concern for the population, social cohesion and individual self-conduct which sought to regulate population, economy and society. ${ }^{19}$ Stoler has led the field in taking up Foucault's cue to considering conduct in terms of desire and affect as realms of colonial governance. ${ }^{20}$ It is not just disciplinary surveillance but governmental regulation that brings practices of prostitution, as well as cohabitation, child rearing and education, within the remit of 
state consideration. These later regulations, inspired in part by developments in international hygiene, were imbricated with earlier models of discipline in Delhi's rescue home in the 1940s.

Thus, while the regulation of prostitution moved towards a more liberal model in the $20^{\text {th }}$ century, links back to more carceral and moralistic techniques remained in evidence. Policies in India, though often inspired by models from Britain or the wider empire, also continued to be filtered through the colonial government's reluctance to invest in broader social welfare, its belief in the embodied and environmental difference of India, and a reluctance to encourage social or political instability. This paper will allow answers to be provided to the following three questions: how did the relationship between Delhi and international policies regarding the regulation of prostitution evolve? What new demands were placed upon the Delhi Administration by these evolving policies? And what were the effects of these changes on prostitutes and the treatment of venereal diseases?

\section{Urban Surveillance: Delhi's Cantonment Regulation Geographies}

\section{Spaces of Surveillance}

In India, lock hospitals were set up spread throughout the territories of the three Presidencies of Madras, Bengal and Bombay during the late $18^{\text {th }}$ century. ${ }^{21}$ Without central permission, many regiments established lal bazars (literally 'red markets') in which prostitutes could dwell and have their health supervised within the cantonments. The cantonment was the space at the heart of $19^{\text {th }}$ century regulatory policies. It was the home of armed forces that were charged with securing the Government of India, which had succeeded the East India Company in 1858. The ratio of British to Indian troops had been increased so as to bolster security, but this investment would only be worthwhile as long as the European soldiers were kept free of venereal disease. The Royal Commission into the Sanitary State of the Army in India (1863) found this not to be the case, as a result of which the lock hospital system was regularised and extended through the 
Cantonment Act (XXII of 1864). This was ahead of the extension of the British Contagious Diseases Acts and the fierce campaign for their repeal.

Combining the United Kingdom's established emphasis on visibility with an 'orientalist sociology' the Indian Cantonment Act divided prostitutes into those that were and were not frequented by Europeans, with only the former coming under regulation. ${ }^{22}$ Ballhatchet has shown that these women were registered within the cantonment, examined every month, and detained in a lock hospital if infected. ${ }^{23}$ Yet there was also a more complex geography that the Cantonment Act created. It demanded a sophisticated system of surveillance such that the spaces, and subjects, under its purview were divided and statistically surveyed ${ }^{24}$ While Foucault's work on discipline has been applied to India, this has often been in a general sense (examining the body, routines, and knowledge) or in a very literal sense (examining prisons, asylums or education). ${ }^{25}$ What the Cantonment Acts represent is the disciplining of public space through surveillance, in conformity to Foucault's four arts of distributions (enclosure, partition, function and rank $)^{26}$

These spaces of surveillance were created, firstly, through enclosing public prostitutes away from 'normal' Indian women. While Indian women were regularly suspected in official reports of promiscuity or immorality, prostitutes were set apart as being both socially lascivious and political dangerous in terms of their effect on British military power. This is reflected in the first categorisation of the Cantonment Act that questioned whether a prostitute was frequented or not by Europeans (regulation 3), with non-registered prostitutes being expelled (regulation 5) from the cantonment or from any prohibited part of the cantonment (7). ${ }^{27}$ Within this enclosed area there would be no public soliciting (27) on the threat of arrest (28), and any woman suspected of being a non-registered prostitute could be reported (29). The Act also gave the cantonment committee the authority to extend their powers beyond the enclosure if other prostitutes were readily available to the soldiers. 
Within the enclosure, space was partitioned into registered homes, which could be inspected at will (21) and maintained to a degree of cleanliness dictated by the Cantonment Committee (22). This is perhaps the clearest example of what Howell refers to as the redundancy of the concept of 'regulation', presumably of a pre-existing object, when the prostitute was so obviously being produced..$^{28}$ Indeed, the review committee appointed by the Military Department, Government of India, stressed that a decrease of the number of prostitutes was not to be aimed at. Rather, it was looked at as '.. an inevitable evil, which may be controlled, but which cannot be got rid of. ${ }^{29}$ The partitions were kept under surveillance by demanding that changes of residence be entered on a register (23), that requests be made to leave the enclosure (24), and that brothel owners be forbidden from allowing prostitutes to exercise 'their calling' when diseased or without a ticket (36).

Information collected from these enclosed and partitioned women was collected in centres of calculation, both the cantonment magistrate's office (9) and the office of the lock hospital (10). The surveyed bodies were given a function, through reading the rules to the prostitute when she registered (11) and giving them a copy of the regulations in their language (14) such that their function as healthy, docile bodies was made clear. Finally, the women were ranked through fortnightly exams (16), the results of which were kept in a register and on the woman's ticket (17), with infected women being forcibly incarcerated in the lock hospital till cured (18). There was further specification within the broader ranking of brothels or prostitutes: firstly by race, as non-Indian prostitutes were much more strictly regulated; and secondly by clientele, with those servicing British troops receiving special attention. Yet there was also a level of ambivalence that created a double system of surveillance whereby rules also had to be created to prevent abuse on the part of the police, which implicitly meant the lower ranked Indian members (31).

During the period of British residency between 1803 and the uprising of 1857 no lock hospital had been established in Delhi, and its Municipal Committee was only created in 
February $1863 .{ }^{30}$ While a lock hospital had been opened in June 1863, within six months opposition from '....influential natives' had caused its suppression. ${ }^{31}$ The opposition was as much to the costs levied on the municipality as the sexual principle, such that when the hospital was reestablished in April 1864 a financial contribution was made from cantonment funds. It appears that four years were then spent assuming that the municipality would regulate prostitution when sufficiently established, although on June $2^{\text {th }} 1868$ the Deputy Commissioner wrote to the Commissioner and Superintendent stressing this would not be possible and requested the extension of the 1864 Cantonment Act to Delhi, although with important qualifications. ${ }^{32}$ The Act was applied to four miles around the cantonment, effectively taking in the whole city of Delhi but not extending beyond the municipal limits. ${ }^{33}$

Being applied to a civilian, as well as military population, certain checks were introduced to temper the extent of surveillance. No charges were to be levied on prostitutes, the lock hospital was not to be open to non-registered women, and no inspection of houses or dictates on cleanliness were to be undertaken because they were claimed to involve too much interference for any place other than a Military Cantonment. ${ }^{34}$ When inspection was necessary they were not to be undertaken by a rank lower than the Superintendent of the City Police or the Sub-Assistant Surgeon (both European), such that the proposed rules '...exclude absolutely the possibility of women being harassed or insulted or plundered by our native subordinates. ${ }^{35}$ The police were not given the power to create a register, thus limiting 'their power for evil.' Local women had protested at being examined by 'native doctors' which was granted as a due complaint '.. to any woman no matter how low she may have sunk.' That said, the Deputy Commissioner had no conception of the complexity of venereal diseases, claiming that diagnosis required little skill and that female assistants who attended half a dozen examinations would be just as competent as a Doctor. Moreover, Native Doctors were to be employed in the Lock Hospital for general duties as '.. people do not expect us to show so much consideration for a woman's feelings when she has become infected.' 
By $21^{\text {st }}$ August 1868 there had still been no extension of the Act. As a result of this the Deputy Commissioner wrote again to the Commissioner claiming that great difficulty was felt without the rules and that the proximity of the city and cantonment made Delhi altogether exceptional, although this was an excuse regularly deployed across the Empire. ${ }^{36}$ While the Indian Contagious Diseases Act (XIV of 1868) was passed for cities without or beyond cantonments, Delhi's proximity to the cantonment meant the act was not required. The national Annual Report on Lock Hospitals for 1869 stressed that there were too many women under no manner of surveillance and that the system across India would fail without tighter regulation. ${ }^{37}$ As a result of this local and national pressure, the rules were extended to four miles around the cantonment on $20^{\text {th }}$ March $1869 .{ }^{38}$ However, by February 1870 a request had to be made to the central government to subsidise the hospital with imperial funds as the cantonment could not support it without financial support from the municipality, which had closed the hospital on January $1^{\text {st }} 1870 .{ }^{39}$ The government was thus forced to agree that the hospital should be considered an imperial cost in March $1870 .{ }^{40}$ Due to these disturbances, by June 1870 the Civil Surgeon, Dr Penny, was still searching for suitable buildings in which to locate a lock hospital and local centres for the examination of prostitutes. ${ }^{41}$ The decision was made to locate one inspection centre in each municipal 'section', which divided the walled city into three, leaving another section for the extra-mural residences. An Indian representative of each centre was responsible for gathering information from the representatives of each moballa (urban walled community) and reporting this to the municipality such that all prostitutes could be registered.

By $13^{\text {th }}$ July Colonel Becker, Delhi's Officer Commanding, complained that the high rate of venereal diseases made any further delay in the opening of the hospital undesirable. ${ }^{42}$ On $4^{\text {th }}$ August the rate of disease amongst the garrisoned troops was claimed to have reached a serious extent and all action was taken to register the prostitutes ahead of the opening of the hospital, which was to be in an old post office. ${ }^{43}$ The building was later reported to be suitable, if not quite central enough, with a large, walled compound such that the place was 'private and retired'. ${ }^{44}$ 
Women were admitted into the examination room and allowed to leave by one door if healthy, if not, they were conducted into a ward for detention and treatment. ${ }^{45}$

\section{Evading Surveillance}

While the planned system of surveillance was daunting in its completeness, the system operated much less effectively. Although all prostitutes were ordered to register themselves, not all did. Those that were registered were often absent from the compulsory fortnightly inspections, while women moved around the city into places where surveillance was less intense. The latter actions had implications not just in terms of evasion, but in terms of the social geography of the city that would have a continued impact after the powers of the Cantonment Act were withdrawn in the twentieth century.

By August $20^{\text {th }} 1870$ the lock hospital was ready and opened in September, with the prostitutes from the cantonment and city being ordered to present themselves. ${ }^{46}$ Despite this, by the end of the year Dr Penny had complained that the prostitutes used by the soldiers were spread throughout the city and were thus very difficult to register. ${ }^{47}$ He made two suggestions that would have increased visibility in the city: allowing the prostitutes to reside in the Fort as they used to; and giving dhais (female assistants) a police escort when visiting the prostitute's home. Both were turned down, the former being termed 'in every respect objectionable' by the Officer Commanding. By February 1871 the Cantonment Sub-Committee pressed Colonel Becker to complain to the Commissioner about the incomplete registration of prostitutes in the city. ${ }^{48}$ He stressed that this completely undermined the working of the lock hospital, because of the occluded gaze of the Cantonment authorities.

This pressure was increased by the issuing of a sanitary report on the hospitals in June 1871 that showed an average increase in venereal diseases across the Army in India, which was blamed on lax enforcement of the cantonment regulations. ${ }^{49}$ Statistics were of utmost importance to the Government's project of establishing control over the myriad processes 
operating across its territories. From trade to climate, birth rates to criminality, statistics were idolised as an objective representation of the real world. ${ }^{50}$ The colonial Indian archive is replete with reams of statistics that provide an invaluable glimpse into the colonial mindset, but not always into the state of affairs as they pertained at the time. The collection of statistics was affected by uneven data collection and the non-cooperation by those being surveyed. In the cases below, rates of venereal disease per mille in the army are problematic because soldiers failed to report their ailments and they may also have gone undiagnosed. As such, they should be taken as an indication of minimum infection levels within the troops. The number of registered prostitutes is indicative only of the effectiveness of the system, not of their actual number. The two sets of statistics do, however, attest that the system did not have a dramatic effect on the rate of venereal diseases in the army, and that registration was both incomplete and ineffective. The Delhi lock hospital report for 1872 showed that the monthly number of registered prostitutes varied between 200 and 228 yet the number attending examination ranged from 135 to 183 . The number retained in hospital ranged from 10 to 30, with gonorrhoea and syphilis dominating the diagnosis. The average length of detention was 10 days, although three extreme cases were detained for 123, 134 and 96 days. ${ }^{51}$ Of the 532 men stationed in the Fort there were 85 admissions in the year for venereal diseases, although 50 of these were before the hospital opened, which was interpreted as a sign that the system would be a success.

However, the report also revealed the way in which the operation of the Act had a profound effect on the governmental and social geography of the city. While the surveillance of the authorities was evaded through non-registration, it was also avoided by prostitutes moving to parts of the city that were less visible to the registering authorities. While the Cantonment Committee had been effective at registering prostitutes, the Municipal Authorities had not, creating an outflow of prostitutes from the cantonment to the city, leaving only 13 registrations in the former and over 190 in the latter in $1873 .^{52}$ 
Even as this geographical shift continued, those registered prostitutes continued to find ways of escaping the spaces of surveillance. A sharp discrepancy between regulation and attendance was made clear in the administration reports of the lock hospital. For instance, there were 423 absences from compulsory inspection during 1872, with an average of 18 absentees at each fortnightly examination. ${ }^{53}$ Absentees were fined eight annas (there were 16 annas in a rupee), although one woman was fined five rupees for repeated absenteeism. The excuses given included accidentally overstaying leave granted to them, forgetting the day of inspection, going on pleasure trips, being ill, and having had deaths in the family.

Problems were also encountered with the other women in the system. Two dhais had been dismissed, the Assistant Surgeon claimed, '... one for receiving bribes, the other for incapacity and constantly being stupefied with opium, ${ }^{54}$ There was even a guarded criticism of the soldiers in the Commanding Officer's report. It was claimed that prostitutes that infected the soldiers were rarely arrested, due to the '... indistinct knowledge the men have of the women who infected them'. ${ }^{55}$ This is inline with the common observation that soldiers themselves objected to regulation and employed their own modes of amnesia, whether induced by alcohol or fear of reprisals for visiting an unregistered prostitute. As Stoler has reminded us, while power relations may structure desire, desire can evade authority, living beyond colonial norms and failing to fortify the colonial means of control. ${ }^{56}$

In response to this suggestion the Assistant Surgeon made three recommendations for reform, which all attempted to refocus the urban surveillance, in terms of locality, surveillance, and administration. ${ }^{57}$ Firstly, it was suggested that the prostitutes be forced to live in a certain locality and not be permitted to move without consent, allowing greater observation by the police and decreased annoyance to the general public. Secondly, that more assistance be given to the Medical Officer besides that of the dhais. And, finally, that one authority, the Cantonment, replace the Cantonment/Municipality split. 
Major McMahon, the Deputy Commissioner, rejected the proposals. He stressed that the prostitutes who had registered themselves were a small proportion of the total, which consisted of various classes, and that ' $\ldots$ a very large number of women would not let a soldier come within a mile of them. ${ }^{58}$ The Deputy Commissioner went on to stress that the assistance of dhais was unclear, whilst the objections to giving the Cantonment Committee authority over a city with a Magistrate appointed by the government were considered too obvious to elaborate on. While all prostitutes have been registered, McMahon insisted that the municipality had the powers to do this, and should enforce them. The opinion of a commander from a local regiment confirmed that most infections were picked up outside of the camp, that the men would not confess who infected them, and thus that the police and municipality had to increase their vigilance. ${ }^{59}$ This is yet another example that confronts the image of the colony as essentially knowable. ${ }^{60}$ Rather, the dense galis (lanes) and bazars (marketplace) of Old Delhi were often impenetrable to administrative surveillance.

\section{Problematised Surveillance}

Evasion by the prostitutes combined with a broader questioning of the lock hospital system eventually condemned the system of regulation in Delhi. This continued high rate of venereal disease in British soldiers was a problem effecting lock hospitals throughout British India. The Secretary to the Punjab, of which Delhi was then part, reported in June 1873 that coolie women, grass cutters, vendors, and villagers near cantonments were the main source of threat. ${ }^{61}$ Yet in Delhi, the proximity of the city to the cantonment re-enforced the need to register more prostitutes. Despite this, the 1873 report showed a decline in the number of registrations to 207, with 13 in the cantonment and 194 in the city. ${ }^{62}$ By 1876 problems were being faced across the country, with commanding officers being ordered to ensure that there were enough prostitutes for the soldiers, in a suitable environment, who were well treated by the authorities. ${ }^{63}$ Despite this, by 1877 the number of registered prostitutes in Delhi had decreased to 171, with only 139 
on average attending fortnightly examination.$^{64}$ For 1878 , the Hospital had an average of only 158 prostitutes on the register, while 72 men were admitted to hospital with venereal diseases from an average strength of just $390 .^{65}$

The failure of the hospitals to impress the authorities led to experimental closures across India at the start of 1885, including Delhi. ${ }^{66}$ The hospital was ordered to reopen in April 1887, there having been 66 soldier admissions for venereal disease from January-March, while only a further 102 were recorded for the rest of the year. ${ }^{67}$ The powers of surveillance were fortified, with any women accused of prostitution by a soldier being forced to have a genital examination, the refusal of which could lead to them being registered as a prostitute by the Honorary Assistant Commissioner. While the number of registered prostitutes increased in 1887 from 76, after reopening, to 97 by December, the registration was obviously inadequate. The 1887 Annual Report claimed that letters and complaints had been received from prostitutes themselves, who suggested that many prostitutes falsely claimed not to service European soldiers, and thus went unregistered.

The restitution of the Delhi Lock Hospital took place just as the British campaign against Indian regulation was to begin in full. Alfred Dyer's sensational reports in the Sentinel of March 1888 detailed the residence of regulated prostitutes on Esplanade Row in Delhi, facing the barracks and Fort, within 80 paces of the Baptist Chapel. ${ }^{68}$ In the same year, the Lock Hospital Report for 1888 showed that Delhi reported an especial increase in venereal diseases, from a ratio of 351 per mille in 1887 , to 509 in $1888 .{ }^{69}$ However, this followed the banning of compulsory examinations, which was enacted as of $1^{\text {st }}$ September 1888 in response to the UK based campaign.

The Delhi Annual Report for 1888 showed that the prostitutes had been told that they could still be examined free of cost, and the local surgeon, WG Thorold, hoped that the prejudice against examination would be overcome by the benefits against disease accrued in past experience. However, he was forced to comment that: 'Of the utter futility of this hope we have 
now the most conclusive evidence' ${ }^{70}$ Not a single woman presented herself, forcing the Lock Hospital to close on $12^{\text {th }}$ October 1888. The building was still rented and stood as a rather tragic relict, with a chowkidar (guard) employed to inhabit the building and restart the system should a prostitute present herself for examination. Thorold continued that the closure of the Hospital was a most noxious measure for the British soldier in Delhi, claiming that 'It would be an admirable example in its completeness were it not so regrettable.' Only strictly enforced attendance was said to protect English soldiers, to provide the government with reliable men, and to prevent sickly children tainted by inherited syphilis from poisoning the nation (presumably Britain, not India.)

The pattern continued in 1889 when the rate remained at 509 per mille. ${ }^{71}$ The Hospital had been reopened on August $1^{\text {st }}$ and messages sent to the women telling them they could attend, although WA Boucher was forced to admit that: 'The utility of the Hospital on the voluntary system at present in vogue is nil, for both the prostitute and the European soldier. ${ }^{72}$ No admission were made in 1889 , or the following year.

An investigation in 1890 showed that more was being spent on Delhi's non-functional Lock Hospital than many others in the Punjab province, of which it was a part, while the venereal disease rate remained high, at 435 in $1890 .{ }^{73}$ By this time the Cantonment Act (XIII of 1889) had come into force, which dictated that prostitutes could not be compulsorily sent to hospital, and that they could not be registered, although they could be expelled from a cantonment for having a contagious (venereal) disease. ${ }^{74}$ There was a ferocious debate in the early 1890s regarding the amount of regulation that could be justified, and whether compulsion was really different to coercion. ${ }^{75}$ The investigations of Katharine Bushnell and Elizabeth Andrew in 1891-92 exposed the ongoing regulation under the new Cantonment Regulations. The government was forced to admit that abolition of the previous system had not been effected and the new Cantonment Act ( $\mathrm{V}$ of 1895) allowed no compulsion, licensing or legal sanction to 
prostitution in cantonments. While prostitutes could be examined, this could not be compulsory or periodical, although the act was repealed in 1897 to allow periodical examinations.

This strengthening of registration within the cantonment can only have exacerbated the distinction between its intensely policed space and the municipality, which had very few powers or resources available to deal with the vastly altered geography of prostitution. The proximity of the city gave soldiers an easily accessible alternative to cantonment prostitutes, and it's density allowed prostitutes to avoid regulation. The stark juxtaposition between the degree of surveillance in the cantonment and the city led prostitutes to desert the former, taking up intramural residence in ways which disrupted the previous acceptance of prostitutes within the city.

For example, in discussing the Cantonment Regulations in 1868, the Deputy Commissioner had stated that regulation 27 , forbidding public soliciting, would be unnecessary as it was practically unheard of in Delhi, and a recently reported case had been '... of an altogether exceptional class ${ }^{76}$ However, in 1873 , just three years after the opening of the lock hospital, the Assistant Surgeon of the city was suggesting that the prostitutes be segregated in a special part of the city to '... prevent them giving annoyance to the public by residing in the general thoroughfares such as Chandni Chowk... ${ }^{97}$ Dyer's Sentinel article showed that women were inhabiting the roads leading off Chandni Chowk, the main artery through the city, adjacent to the Fort by 1888. The re-enforcement of inspection from 1897 guaranteed this trend well into the next century, during which a new configuration of administrative and non-governmental bodies would attempt to regulate the prostitute and the diseases with which she was indelibly associated.

\section{International Hygiene: Regulating Delhi’s Prostitutes and Population}

Following the stinging criticism in the late nineteenth century regarding the Government of India's Contagious Diseases Acts and Cantonment Acts, the state was incredibly wary in the 1900s of any action that resembled the military regulation of vice (despite wartime powers that 
had veered back towards these techniques). The most obvious expression of this came in July 1918 when the Adjutant-General issued a memorandum on behalf of the Commander-in-Chief condemning any orders that condoned soldiers visiting brothels under medical control, stating that any remaining prostitutes would be expelled from cantonments. ${ }^{78}$ Prostitutes and brothels would be pursued and harassed outside the cantonment, yet in a more discreet fashion and in cooperation with the civil authorities. As such, the memorandum marked the final rejection of formal military regulation and the shifting of the imperative to act onto municipalities and local administrations.

The nature of this action in Delhi would be radically affected by the impact of the capital transfer that took place in 1911, which crafted Delhi Province out of the Punjab and put it under the direct control of the central government. The construction of the new capital and a new cantonment to the south of Old Delhi contributed to an influx of people into the city. This swelled the population of Delhi city from 232837 in 1911 to 246987 in 1921, to 347592 in $1931 .^{79}$ A new railway station by the southwest city wall increased the flow of transitory populations, while the construction of Delhi University to the north of the city increased the student population of the city. Despite the construction of a new cantonment, the Fort continued to billet large numbers of troops, especially during times of social unrest when more soldiers were stationed in Old Delhi. The city remained under the control of the partially elected Delhi Municipal Committee (DMC) and the centrally appointed Delhi Administration, while the capital was run by a separate municipal committee and maintained by the Public Works Department. Both cities, however, fell under the remit of other single authorities such as the Delhi Improvement Trust, the New Delhi Development Committee, and the Delhi Criminal Investigation Department. As such, Delhi's period of relatively independent sovereignty, when the Chief and Deputy Commissioner could run the city with little interference from the Punjab provincial government, abruptly came to an end in 1911. The Delhi Administration now found itself contending with multiple and fragmented governmental agencies, as well as an increasingly 
congested and disruptive population, within which the threat to social stability and public health posed by the prostitute and her clientele was an increasing worry.

The DMC responded to the demands of the city dwellers, which had begun to manifest themselves in a series of petitions, beginning in 1912, requesting the ejection of prostitutes from specific bazars. ${ }^{80}$ While in part a reaction to social reformist notions of sexual propriety, and the aggravated social conditions of a congested city, these petitions must also be seen as a reaction to the forcing of prostitutes out of the military bazars and into the city. ${ }^{81}$

These negotiations are fascinating in many regards, but the nature of the urban politics involved has been explored elsewhere. ${ }^{82}$ However, unlike the new imperial histories of nineteenth century government policy, the international and imperial networks informing urban politics have not always been made apparent. This is particularly incongruous given that Darwin has singled out the openness of the "late-colonial state" as one its defining features. ${ }^{83}$ The wider world constantly impressed itself upon the Delhi Administration, via memos from the Government of India and the Secretary of State for India in London, and by international campaigning bodies.

\section{Relational Spaces: the Royal Commission on Venereal Diseases, 1916}

One of the major landmarks in the history of ideas regarding sexual health in the United Kingdom centred on the Royal Commission on Venereal Diseases, whose report was issued in February 1916. Discussions about eugenics and race suicide from the 1890s onwards had led to fears about declining birth rates, infant mortality and the rate of venereal diseases in the general population. Hall has shown that there had been requests for a Royal Commission on the subject since the 1890s, but that the Cantonment Regulations debate was still too fresh in the

government and public mind to entertain a further debate. ${ }^{84}$ Yet in the early twentieth century a new coalition of activists started pressing for government action in the sexual realm. The double 
standard argument (between the sexes) was mobilised using scientific evidence to suggest that male infidelity was infecting the womenfolk of the country and ruining the nation itself. ${ }^{85}$

The commission's conclusions suggested that the government should make testing and medical care for venereal diseases available for everyone, not just the military, and that the public had to be educated about the risks posed by these diseases. Much of the campaigning around the Commission addressed prostitution, and although in much of the actual literature the prostitute remained a silent, or at least marginalised, figure she still underlay many of the major concerns. This was as much the case in the colonies as in London. The effect of the report on Delhi reveals the city to be a relational space in imperial networks of regulation. ${ }^{86}$ Yet what this example also shows is that these spaces of relation and network also came up against geographies of difference and barriers to international flows.

In October 1916 the Chief Commissioner of Delhi endorsed the findings of the Royal Commission and requested Major M Corry, the Chief Medical Officer, to comment upon its recommendations.$^{87}$ Corry showed that the ratio of venereal to other diseases treated in Delhi Province in the last ten years had varied between one and two per thousand, there being between 1500 and 2000 cases of gonorrhoea a year, while syphilis had risen to over 4200 reported cases in 1911, averaging at between 2000 and 3000 cases otherwise. Because many patients visited local hakims and vaids (local authority figures and health practitioners), as opposed to professionals trained in western medicine, these figures have to be presumed to be underestimates. It was acknowledged that the people of Delhi needed greater education and instruction on the diseases, and that greater funds would be needed for Salvarsan injections, which were the best-known treatment at that time for syphilis.

However, Dr KS Sethna, the Indian-born yet English educated Health Officer, was also asked for his opinions and immediately pointed out the problems of what Vaughan referred to as the transformation of European biomedical practice in the colonial environment. ${ }^{88}$ He stressed, on $21^{\text {st }}$ December 1916, that the views of British doctors would not hold good in India. Firstly, 
there were no accurate figures on the rate of venereal diseases in Delhi, and even notifying diseases (making it illegal not to report them) had not worked in the past. While Sethna agreed with the need for more facilities, he recommended no action, stating that:

(t)he suggestions put forward by the Royal Commission are excellent for England- but they are not so for Delhi. Great Britain never touched this question before it tackled fully the question of tuberculosis, medical inspection of school children and many other important subjects... People in India are ignorant of the modes of transmission of tuberculosis, malaria, plague etc, but they are fully alive to the cause which gives rise to venereal diseases. ${ }^{89}$

The Chief Commissioner disagreed and replied on $12^{\text {th }}$ January 1917 that local people did not understand the effect of venereal diseases on stillbirths, the condition of offspring, or the need for early medical advice. The Chief Commissioner requested a pamphlet to be drawn up, which Sethna duly did.

In this publication the three stages of syphilis were depicted in grisly detail; the spoiling of a persons blood was said to eventually destroy ones strength, making a man's condition so bad that '...everyone hates him and the result is this, that in this very bad condition after suffering [he] dies bit by bit. ${ }^{90}$ However, this was not the end of the disease's pernicious effects, and in elaborating the further consequences Sethna moved on to explicitly address the implicit cause that had been behind much of this debate. The pamphlet stressed that offspring could carry the seed of the disease, such that '.. even the offspring has to pay for the sin committed by the father.' Sethna went on that to save ones self and ones progeny one must avoid making 'mistakes' because the prime source of the disease was prostitutes. As such, prostitutes should be strictly avoided, which was claimed to be clearly dictated in religious and moral books of all faiths. If infected, one needed swift treatment and to make a solemn assertion not to commit such a deed in the future. Sethna concluded that precautions were necessary so that the health of 
the masses did not get compromised. The health of the population, rather than just the British soldiery, became of increasing importance in Delhi, although this was also related to continuing international influence on the medical spaces of the city.

Spaces of Social Hygiene

As an outcome of the 1916 Royal Commission, the National Council for Combating Venereal Diseases (NCCVD, renamed the British Social Hygiene Council in 1925) had been acknowledged as an authoritative body for spreading knowledge about medical science and encouraging the education of the population. While predominantly based in the United Kingdom, Macpherson has stressed that the NCCVD also promulgated a world-wide approach, establishing headquarters around the globe, including a base in Bombay in 1918. ${ }^{11}$ As such, the NCCVD contributed to the emerging field of 'imperial hygiene' that focused on individual responsibilities to public health. ${ }^{92}$ This focus on the population and broader issues of government stood in contrast to earlier models that focused on individual threat and selfdiscipline.

This evolution began in Europe and was exported to its colonies although in mediated forms. These imperial interests took in the broader field of 'social hygiene' which focused specifically on venereal diseases as a dangerous presence at the intersection of the individual and the population. This engendered fears that saw 'red-light districts' being targeted in the United States of America and Europe as part of attempts to make urban space visible and controlled. ${ }^{93}$ Although operating around the globe, the NCCVD was still more 'international' than 'global' in that it operated between states and advised governments directly.

The Council made three recommendations to the Government of India in 1922 regarding: firstly, facilities to treat the Indian population; secondly, popular education, and; finally, the possibility of forming voluntary associations to help in this work. ${ }^{94}$ The Government 
responded that action, in Delhi as elsewhere, on the first two recommendations was being taken, but that financial stringency meant that more extensive operations would have to wait.

By October 1926 the Director of Medical Services in India felt the waiting had gone on too long. ${ }^{95}$ In a circulated memorandum he claimed that the health statistics of 1925 had shown that venereal diseases had increased over the last year, to a rate of two or three times that in the United Kingdom, where rates of syphilis had been halved between 1920-24. The recommendations of the 1916 Royal Commissioner were repeated: the need for free testing, treatment and supply of medicine, and education of the public. The memorandum was forwarded to local governments, emphasising that Delhi had one of the higher infection rates. Delhi's Deputy Commissioner reported on $1^{\text {st }}$ February 1927 that the Chief Medical Officer was considering a venereal diseases clinic in Delhi and requested the funds. These would be used to establish free treatment and dispensaries at the Civil Hospital and also at the Victorian Zenana (women's) Hospital, especially an outpatients clinic for prostitutes.

In March 1927 the funds were granted, with additional money provided in December. By March of 1928, 1775 patients had been treated at the Civil Hospital Clinic, with the figures rapidly rising to 3157 for 1928-29 and 6145 for 1929-30. ${ }^{96}$ In 19281173 of the patients were admitted to the Special Venereal Ward, and funding was guaranteed for further expansion. ${ }^{97}$ The number of inpatients increased to 1230 for 1929-29 and for 1929-30 1278 at the Civil Hospital and 238 at the Victoria Zenana Hospital. ${ }^{98}$ The success of the projects led the Chief Commissioner to recommend further clinics outside the city, in the Paharganj and Bara Hind Rao Dispensaries. This was under the coordination of a subcommittee established to explicitly deal with venereal diseases and 'women of ill fame'. The figures attest to the success of the ward in transforming Delhi as a medical space in which venereal diseases could be both acknowledged and treated in the general population, although the investment was driven, in large part, by a desire to protect the military as much as the Indian people. ${ }^{99}$ 
Spaces of Moral and Social Hygiene

While the Association for Moral and Social Hygiene (AMSH) made its entrance onto the Delhi scene in 1935, it had been campaigning through the 1920s for the abolition of state regulated prostitution throughout the British Empire. Its campaigns continued to target brothels in cantonments, to champion facilities for the free treatment of venereal diseases, and to spread the abolitionist principle. ${ }^{100}$ As such, the AMSH shared many of the principles of the NCCVD, and some of the sentiments of earlier social purity movements, but developed its own unique medico-moral complex that influenced, and was influenced by, wider trends.

After the First World War the League of Nations was established to act as an international diplomatic body, not just to address peacekeeping but also to work towards international standards of justice and welfare. The AMSH later claimed to have been amongst the first to impress the fight against trafficking and the regulation of vice on the League, beginning in $1920 .{ }^{101}$ In 1921 the League held a conference in Geneva to discuss what its members were doing to suppress 'traffic in women and children'. ${ }^{102}$ The convention of 1921 , which India and Britain signed, worked to encourage its members to suppress the traffic in women and children and, after 1934, to work against the brothel system, souteneurs (a person living off the wages of prostitutes) and obscene publications. ${ }^{103}$ The League also published its own report into traffic in the East in 1932, and continued to demand annual reports from member states on their actions to suppress trafficking, with firm support from the AMSH. ${ }^{104}$

In May 1928 the Association was requested to send a representative to Calcutta for three years to work towards the closure of brothels. ${ }^{105}$ Meliscent Shephard was chosen for this task, and continued to devote herself between 1929 and 1946 to spreading the AMSH word across the subcontinent. ${ }^{106}$ Shephard went on to tour the country, working with various different voluntary associations, constantly striving to assimilate concerns over trafficking with a commitment to the closure of brothels. ${ }^{107}$ In 1932 the AMSH headquarters was moved to New Delhi, allowing Shephard to turn her attentions to the local administration. ${ }^{108}$ 
Since the early 1920s local legislatures throughout India had been passing Acts to prevent prostitution, and by the 1930s these had taken on the moralistic tone of the 'Suppression of Immoral Traffic Acts', known as the SITAs. ${ }^{109}$ Shephard returned to Delhi in May 1935, having been in Simla (the summertime capital of British India) assisting a select committee discussing the SITAs. ${ }^{110}$ The act provided for punishing the keeping of a brothel, living on immoral earnings, procuration, and the importation or detention of women or girls for prostitution.

In pushing for the spread of such legislation, Shephard had circulated a questionnaire that provincial organisations were to use to question their locality. The questionnaire concluded by claiming the authority of the League of Nations and reproducing the report from the Commission of Enquiry into Traffic in Women and Children in the East, although the problem was stressed to be internal to India. The questionnaire directly asked if there was any legislation for the suppression of immoral traffic, to which Delhi had no answer.

While there was no immediate action, by 1938 pressure was mounting. The central Government was pressing each province to display what it had been doing to tackle trafficking and the exploitation of prostitution, following pressure from the League of Nations. ${ }^{111}$ The Chief Commissioner replied that he was considering extending a SITA to the region, an advance copy of which had been delivered by Shephard in December $1935 .{ }^{112}$ Under pressure from both the Government and social campaigners, the Delhi SITA was passed in December 1939.

The SITA also punished solicitation, living on the earnings of prostitution, procuration, importing women for prostitution, and detention of prostitutes. However, despite the naming of the act, it was used throughout Indian much more for the suppression of immorality than of trafficking. The SITAs were used to complement ongoing efforts to clean the centre of Indian cities if public prostitution and brothels. In the case of the latter, girls aged under 16 could be removed and placed in the custody of a suitable agency who would have the powers of a parent over her. 
The Chief Commissioner placed extra rules in the schedule of the Delhi SITA to clarify the conduct of such approved institutions. Having removed someone from a brothel, the first action was to test the girl for venereal diseases in the nearest Women's Hospital, and to register her as an outpatient for treatment if necessary. The girls were to be protected from 'evil influences' and be provided with a separate bed, clothes, wholesome food and suitable education and employment such as housework or sewing. No girl would be allowed visitors or letters without the permission of the head of the institution and any necessary visits to the police or a court would be accompanied by a member of staff. The only approved institution was the Rajpore Road Asra (shelter) Ghar (home).

The Delhi Provisional Committee for Rescue Work's, which ran the home, had made it clear that it wished that the home be run on 'strict disciplinary lines'. It would be a mistake to portray the home as unnecessarily punitive as there had been terrible abuses of children in brothels throughout India and the rules were as much to protect the children as to prevent them leaving. The home itself was designed as an amalgam of a workhouse, a lock hospital, and the reformatory Magdalene Homes of the pre-1900s. ${ }^{113}$ Inline with the shift from solely medical notions of physical hygiene to moral and social hygiene discourses, the women were also trained in self-conduct as with the reformatory homes of Victorian Britain. However, women and girls always had the option of leaving these homes in the United Kingdom, although they would be passed on to the more disciplinary Lock Asylums should they be infected. ${ }^{114}$ Yet, in the Delhi home, like in the Lock Hospitals of the Cantonment Regulations, girls were incarcerated and cured of disease. Rather than being an anomaly, this example fits into a long tradition of colonial disciplinary institutions being more carceral and segregated than their European equivalents. These institutions and practices survived well into the era of proto-welfarism and remind us that within an era of general concern for the health of the population and gradual social reform, there remained specific concerns for polluting and social threatening subjects that provoke comparisons with the disciplinary practices of the cantonment acts. 


\section{Conclusions}

Although relating to various wider developments in the politics and technology of prostitution regulation, Delhi has a specific narrative because of its urban topography and unique political and administrative setup. The proximity of the Fort to the city made the Indian CDA unnecessary but did create the need to tailor the cantonment regulations' disciplinary surveillance to a civil, municipal sphere. This proximity allowed prostitutes to move through the city and evade surveillance, as could the soldiers seeking them out. The unwillingness or inability of the municipality to register prostitutes encouraged them into the city. Once there they created a perceived social and biological threat to the urban population that would be tackled by a new raft of regulatory measures in the twentieth century. Whilst many of these measures were local initiatives, they were conjoined by measures that had their origins in London, Geneva and countless other sites in which the threat of the prostitute to the population, not just the military, had been tackled.

These new geographies of regulation were more those of liberal government, standing back and advising, hemming and canalising the movements and decisions of the population. This took place through propaganda, clinics, anti-brothel campaigns and rescue homes. These events and places were the manifestations of both imperial and international hygiene. The fragmentary nature of the second half of this paper sought to reflect the fractured authority of the Delhi Administration, which increasingly found demands upon its powers being made not just by local petitioners, as routed through the Municipal Committee, but also by national and international experts, campaigners and conventions. The Administration's response was to accept the extrastate origins of tactics which were emerging to deal with prostitution and venereal disease, and to use them to 'out-source' some aspects of government to clinics and charities who specialised in the sciences of hygiene. 
As such, we can return to the questions posed at the beginning of this paper. The relationship between policies in Delhi to those in the international arena evolved in terms of the institutions that mediated local policy and the broader world. Whilst in the $19^{\text {th }}$ century the Government of India, albeit under pressure from Dyer, Bushnell, Andrew and others, debated and implemented regulations it observed from around the world, during the 1900s a host of external experts were campaigning to introduce their regulations into the Indian late-colonial state, from the Social Hygiene organisations to the League of Nations. This placed a host of new demands upon the Delhi Administration, in response to which it furthered the policy of outsourcing the regulation of prostitutes, which had begun in the 1870 s when pressure was placed on the Delhi Municipal Committee to match the regulatory standards of the Cantonment Committee. The AMSH, in particular, came to play a key role in advising the Commissioner on draft bills for the SITA, the League of Nations, and the Rescue Home. These changes were beneficial to those members of the wider public who had not previously had access to western medical treatment for venereal diseases, and who wished prostitutes to be cleared from the streets. For the women themselves, the SITAs did offer certain protections against exploitation by pimps and traffickers, but these benefits must be off-set by their exclusion from the centre of Old Delhi, and from access to the civic and medical institutions that were strengthening within its walls. 


\footnotetext{
${ }^{1}$ M. Crinson, 'Book review', Planning Perspectives 24:1, (2009), 134-135. 134.

${ }^{2}$ R. Frykenberg, Delhi through the ages: essays in urban history, culture and society, (Delhi, 1986).

${ }^{3}$ W. Dalrymple, The last Mughal: the fall of a dynasty, Delhi, 1857 (London, 2006).S. Bhattacharya, Rethinking 1857 (New Delhi, 2007).

${ }^{4}$ However, see N. Gupta, Delhi between two empires, 1803-1931: society, government and urban growth (Delhi, 1981).
}

${ }^{5}$ A. King, Colonial urban development: culture, social power and environment (London, 1976). R. Irving, Indian summer: Lutyens, Baker, and Imperial Delhi (New Haven; London, 1981). S. Legg, Spaces of Colonialism: Delhi's Urban Governmentalities (Oxford, 2007).

${ }^{6}$ G. Pandey, Remembering partition: violence, nationalism and history in India (Cambridge, 2001). V. F.Y. Zamindar, The long partition and the making of modern South Asia (New York, 2007).

${ }^{7}$ P. McHugh, Prostitution and Victorian social reform (London, 1980), J. R. Walkowitz, Prostitution and Victorian society: women, class, and the state (Cambridge, 1982).

${ }^{8}$ P. Levine, 'Rough usage: prostitution, law and the social historian', in Wilson (ed) Retbinking social history: English society 1570-1920 and its interpretation (Manchester, 1993). P. Bartley, Prostitution: prevention and reform in England, 1860-1914 (London, 2000). J. Weeks, Sex, politics and society: the regulation of sexuality since 1800, (London; New York, 1989 [1981]).

${ }^{9}$ A. L. Stoler, Race and the education of desire: Foucault's history of sexuality and the colonial order of things, (Durham, NC; London, 1995). ;

${ }^{10}$ R. Hyam, Empire and sexuality: the British experience (Manchester, 1990). R. Phillips, 'Imperialism, sexuality and space: purity movements in the British Empire', in Blunt and McEwan (ed) Postcolonial geographies, (London, 2002).

${ }^{11} \mathrm{~K}$. Ballhatchet, Race, sex and class under the Raj: imperial attitudes and policies and their critics, 1793 1905, (London, 1980). P. Howell, Geographies of Regulation: Policing Prostitution in Nineteenth-Century 
Britain and the Empire (Cambridge, 2009). P. Levine, Prostitution, race and politics: policing venereal disease in the British Empire, (London, 2003). R. Phillips, Sex, politics and empire: a postcolonial geography, (Manchester, 2006). K. K. Jordan, From sacred servant to profane prostitute: a bistory of the changing legal status of the Devadasis in India, 1857-1947 (New Delhi, 2003) A. Tambe, Codes of Misconduct: Regulating Prostitution in Late Colonial Bombay (Minneapolis, 2009. S. Banerjee, Dangerous outcasts: the prostitute in nineteenth century Bengal, (Calcutta, 1998). S. M. Raj, Prostitution in Madras: a study in bistorical perspective, (Delhi, 1993).

12 Delhi State Archives (henceforth DSA) Resident's files/Lock Hospital (henceforth LH)/1873/75: Annual Return Of The Lock Hospital 1872

${ }^{13}$ Ballhatchet op. cit. 161.

${ }^{14}$ A. Bashford, Imperial bygiene: a critical history of colonialism, nationalism and public health, (Basingstoke, 2004). B. Metzger, 'Towards an international human rights regime during the interwar years; the League of Nations' combat of traffic in women and children', in Grant, Levine and Trentmann (ed) Beyond Sovereignty: Britain, Empire and Transnationalism, c.1880-1950, (Basingstoke; New York, 2007).

${ }^{15}$ D. Massey, For Space, (Sage, 2005).

${ }^{16}$ For instance, D. Scott, 'Colonial governmentality', Social Text 43:(1995), 191-220.G. Prakash, Another reason: science and the imagination of modern India (Princeton, N.J; Chichester, 1999). P. Chatterjee, The politics of the governed: reflections on popular politics in most of the world (New York, 2004).

${ }^{17}$ D. Arnold, Colonizing the body: state medicine and epidemic disease in nineteenth-century India (Berkeley, 1993).

18 M. Foucault, Discipline and Punish: The Birth of the Prison, (Harmondsworth, 1977), also see S.

Pierce and A. Rao, Discipline and the Other Body: Correction, Corporeality, Colonialism (Durham, 2006).

${ }^{19}$ M. Foucault, Security, Territory, Population: lectures at the Collège de France 1978, (Basingstoke; New York, 1978 [2007]). 
${ }^{20}$ A. L. Stoler, 'Intimidations of empire: predicaments of the tactile and unseen', in Stoler (ed) Haunted by empire: geographies of intimacy in North American history, (Durham; London, 2006). Also see S. Legg, 'An intimate and imperial feminism: Meliscent Shephard and the regulation of prostitution in colonial India', Environment and Planning D: Society and Space advance online publication:(2009),

${ }^{21}$ Ballhatchet, op. cit. 11 .

${ }^{22}$ P. Levine, 'Orientalist sociology and the creation of colonial sexualities ', Feminist Review 65: Summer, (2000), 5-21.

${ }^{23}$ Ballhatchet, op. cit. 40.

${ }^{24}$ C. Dandeker, Surveillance, power, and modernity: bureaucracy and discipline from 1700 to the present day (Cambridge 1990).

${ }^{25}$ For instance, Arnold, Colonizing the body: state medicine and epidemic disease in nineteenth-century India, D. Arnold, 'The colonial prison: power, knowledge and penology in nineteenth-century India', in Arnold and Hardiman (ed) Subaltern Studies VIII, (Delhi, 1994). S. Seth, Subject Lessons: The Western Education of Colonial India (Duke University Press, 2007).

${ }^{26}$ Foucault, Discipline and Punish: The Birth of the Prison, 141-149.

${ }^{27}$ DSA/LH/1864/1a: Cantonment Regulations

${ }^{28}$ Howell, 'Race, space and the regulation of prostitution in colonial Hong Kong: colonial discipline/imperial governmentality', 232.

${ }^{29}$ DSA/LH/1864/1a: Cantonment Regulations

${ }^{30}$ M. Pershad, The History of the Delhi Municipality 1863-1921, (Allahabad, 1921), 7.

${ }^{31}$ DSA/LH/1870/19: Punjab Government Gazette Lock Hospital Summarily Closed

${ }^{32}$ DSA/LH/1868/4: Prevention Of Venereal Diseases In The City Of Delhi

${ }^{33}$ DSA/LH/1870/17: Dr Penny Will Be Invested With The Powers Described In Rule 33

${ }^{34}$ DSA/LH/1868/4: Prevention Of Venereal Diseases In The City Of Delhi 
${ }^{35}$ Ibid.

${ }^{36}$ DSA/LH/1868/8: Rules for the prevention of venereal diseases

${ }^{37}$ DSA/LH/1869/12: Annual Report

${ }^{38}$ DSA/LH/1870/19: Punjab Government Gazette Lock Hospital summarily closed

${ }^{39}$ DSA/LH/1870/54: Annual Report on Lock Hospitals 1870

${ }^{40}$ DSA/LH/1870/20: Sanction Of The Govnt Of India To The Continuance Of The Lock

Hospital At Delhi

${ }^{41}$ DSA/LH/1870/27: Selection of building for Lock Hospital

${ }^{42}$ DSA/LH/1870/35: Lock Hospital At Delhi

${ }^{43}$ DSA/LH/1870/36: The Building Of The Old Hospital Selected For The Lock Hospital

${ }^{44}$ DSA/LH/1873/75: Annual Return Of The Lock Hospital 1872

${ }^{45}$ Ibid.

${ }^{46}$ DSA/LH/1870/39: Inspection Of Prostitutes

${ }^{47}$ DSA/LH/1870/54: Annual Report On Locks 1870

${ }^{48}$ DSA/LH/1871/57: Lock Hospital Registration Of Prostitutes

${ }^{49}$ DSA/LH/1872/67: Review By The Sanitary Commissioner Of The Working Of The Lock Hospital 20th March 1872

${ }^{50}$ S. Legg, 'Governmentality, Congestion and Calculation in Colonial Delhi', Social and Cultural Geography 7:5, (2006), 709-729, T. Porter, The rise of statistical thinking, 1820-1900, (Princeton, N.J., 1986).

${ }^{51}$ DSA/LH/1873/75: Annual Return Of The Lock Hospital 1872

${ }^{52}$ Ibid.

${ }^{53}$ Ibid.

${ }^{54}$ DSA/LH/1873/74: Annual Statement Of The Lock Hospital Of Delhi 1872

${ }^{55}$ DSA/LH/1873/75: Annual Return Of The Lock Hospital 1872 
${ }^{56}$ Stoler, 'Educating desire in colonial South-East Asia: Foucault, Freud, and imperial sexualities', in (ed) 45 .

${ }^{57}$ DSA/LH/1873/74: Annual Statement Of The Lock Hospital Of Delhi 1872

${ }^{58}$ DSA/LH/1873/74: Annual statement of the lock hospital of delhi 1872

${ }^{59}$ DSA/LH/1873/75: Annual Return Of The Lock Hospital 1872

${ }^{60}$ L. Manderson and M. Jolly, 'Introduction: Sites of Desire/Economies of Pleasure in Asia and the Pacific', in (ed) Sites of desire, economies of pleasure: sexualities in Asia and the Pacific, (Chicago; London, 1997).

${ }^{61}$ DSA/LH/1872/76: Lock Hospital Report For 1872

${ }^{62}$ DSA/LH/1873/77: Lock Hospital Report

${ }^{63}$ Ballhatchet, op. cit., 47.

${ }^{64}$ DSA/LH/1877/92: Statement on ratios of venereal diseases in Lock Hospitals, 1892.

${ }^{65}$ Asia, Pacific and Africa Collections, India Office Records, at the British Library, London (hereafter IOR)/V/24/2291: Report on the Lock Hospitals in the Punjab, 1878-1890

${ }^{66}$ DSA/LH/1887/106: Re-opening certain lock hospitals

${ }^{67}$ IOR/V/24/2291: Report on the Lock Hospitals in the Punjab, 1878-1890

${ }^{68}$ Ballhatchet, op. cit. 58.

${ }^{69}$ Indian National Archives (henceforth NA)/Home/Sanitary/1889/3-7

${ }^{70}$ IOR/V/24/2291: Report on the Lock Hospitals in the Punjab, 1878-1890

${ }^{71}$ NA/Home/Sanitary/1890/40-43

${ }^{72}$ IOR/V/24/2291: Report on the Lock Hospitals in the Punjab, 1878-1890

${ }^{73}$ NA/Home/Sanitary/1891/21-23: Report on Voluntary Hospitals in th Punjab for the Year 1890 
${ }^{74}$ NA/Home/Sanitary/1893/7-9: Proposal To Direct Cantonment Magistrates To Do All In Their Power To Enforce The Carrying Out Of The Instructions Of The Quarter Master General Against Prostitutes In Regimental Bazaars, Etc.

${ }^{75}$ P. Levine, 'Rereading the 1890s: venereal disease as 'constitutional crisis' in Britain and British India', The Journal of Asian Studies 55:3, (1996), 585-612

${ }^{76}$ DSA/LH/1868/4: Prevention Of Venereal Diseases In The City Of Delhi

${ }^{77}$ DSA/LH/1873/74: Annual Statement Of The Lock Hospital Of Delhi 1872

78 'Victory in India. The Cantonment System Crumbling' The Shield 1919 Third Series 11(2): 7985,79 .

${ }^{79}$ Legg, Spaces of Colonialism op. cit. 166.

${ }^{80}$ DSA/Chief Commissioner's files (henceforth CC)/Local Self Government (henceforth LSG)/1940/2(97): Note With Regard To The Action Taken By The Dmc In Connection With The Removal Of Prostitutes From The Prohibited Area Of Delhi, 9th October 1940

${ }^{81} \mathrm{~J}$. Whitehead, 'Bodies clean and unclean: prostitution, sanitary legislation, and respectable femininity in colonial north India', Gender and History 7:1, (1995), 41-63.

${ }^{82}$ Gupta, Sexuality, obscenity, community: women, Muslims, and the Hindu public in colonial India. Tambe, op. cit.

${ }^{83}$ J. Darwin, 'What was the late colonial state?' Itinerario XXIII:3/4, (1999), 73-82.

${ }^{84}$ L. A. Hall, 'Venereal diseases and society in Britain, from the Contagious Diseases Acts to the National Health Service', in Hall and Davidson (ed) Sex, sin and suffering: venereal disease and European society since 1870 (London, 2001). 122.

${ }^{85} \mathrm{~L}$. Bland, "Cleansing the portals of life': the venereal disease campaign in the early twentieth century', in Langon and Schwarz (ed) Crises in the British State 1880-1930, (London, 1985).

${ }^{86}$ See A. Lester, 'Imperial circuits and networks: geographies of the British Empire ', History Compass 4:1, (2006), 124-141. 
${ }^{87}$ DSA/CC/Home (Education)/1917/18B

${ }^{88}$ M. Vaughan, Curing their ills: colonial power and African illness, (Cambridge, 1991). 132.

${ }^{89}$ DSA/CC/Home (Education)/1917/18B: Recommendations Of The Royal Commission On Venereal Diseases

${ }^{90}$ DSA/CC/Home (Education)/1917/18B, translated from Hindi by Dr Prasannanshu:

Recommendations Of The Royal Commission On Venereal Diseases

${ }^{91}$ K. L. MacPherson, 'Health and empire: Britain's national campaign to combat venereal diseases in Shanghai, Hong Kong and Singapore', in Hall and Davidson (ed) Sex, sin and suffering: venereal disease and European society since 1870 (London, 2001).

${ }^{92}$ Bashford, Imperial hygiene, op. cit.

${ }^{93}$ Mort, Dangerous sexualities: medico-moral politics in England since 1830, 131.

${ }^{94}$ DSA/CC/Education/1923/5(13): Preventative Measures Against The Spread Of Venereal Diseases In India

${ }^{95}$ DSA/CC/Confidential (Education)/1927/2B: Scheme To Prevent The Spread Of Venereal Diseases Amongst The Civil Population In India ${ }^{96}$ DSA/CC/Education/1929/5(24): Control Of Venereal Diseases

${ }^{97}$ DSA/CC/Home (Education)/1928/5(50)B: Control Of Venereal Diseases

${ }^{98}$ DSA/CC/Eduction/1930/5(47): Control Of Venereal Diseases

${ }^{99}$ DSA/CC/Confidential (Education)/1927/2B: Scheme To Prevent The Spread Of Venereal Diseases Amongst The Civil Population In India

${ }^{100} \mathrm{~J}$. A. Laite, 'The Association for Moral and Social Hygiene: abolitionism and prostitution law in Britain (1915-1959) ', Women's History Review 17:2, (2008), 207-223.

101 'The Association for Moral and Social Hygiene and the League of Nations: Traffic in Women and Children’ The Shield 1934 Fifth Series III(2): 53-56 
102 See D. Gorman, 'Empire, internationalism, and the campaign against the traffic in women and children in the 1920s', Twentieth Century British History 19:2, (2008), 186-216. S. Legg, 'Of Scales, Networks and Assemblages: Trafficking in Women and Children and the scalar apparatuses of the League of Nations and Government of India', Transactions of the Institute of British Geographers NS 34:2, (2009), 135-155.

103 S. Jeffreys, The idea of prostitution, (Melbourne, 1997). 13.

104 'Equal Moral Standard in the British Empire' The Shield 1925 Third Series IV(6); 'Vice Areas in India' The Shield 1928 Third Series V(4): 167-169

105 'Miss Shephard's Campaign in Calcutta' The Shield 1930 Third Series VI(2): 73-78

${ }^{106}$ Legg, 'An intimate and imperial feminism' op. cit.

${ }^{107}$ Records of the Association for Moral \& Social Hygiene (3AMS/C/5). The Women's Library, London Metropolitan University

${ }^{108}$ M. Shephard, 'Memories of the Association for Moral and Social Hygiene in India 19281947', The Sbield Fifth Series, XI:1, (1948), 35-46.

${ }^{109}$ For instance: The Madras Suppression of Immoral Traffic Act (V of 1930); The Bengal Suppression of Immoral Traffic Act (VI of 1933); The United Provinces Suppression of Immoral Traffic Act (VIII of 1933); The Punjab Suppression of Immoral Traffic Act (IV of 1935)

${ }^{110}$ DSA/CC/Home/1935/147B: Activities Of The Association For Moral And Social Hygiene ${ }^{111}$ DSA/CC/General/1938/694: League Of Nations, Traffic In Women And Children. Conclusion Of An International Convention For Suppression The Exploitation Of Prostitution ${ }^{112}$ DSA/CC/Home/1936/85B: Question Of The Extension To Delhi Of The Punjab Suppression Of Immoral Traffic Act 1935

${ }^{113}$ Bartley op. cit., L. Mahood, The Magdalenes: prostitution in the nineteenth century, (London; New York, 1990). 
${ }^{114}$ Mahood op. cit. 76. 